\title{
ÉRVÉNYES-E GÖDEL TÉTELE A „MINDENSÉG ELMÉLETÉRE"?
}

\section{IS GÖDEL'S THEOREM VALID TO THE THEORY OF EVERYTHING?}

\author{
Bognár Gergely \\ fizika-filozófia tanár, Révai Miklós Gimnázium és Kollégium, Gyốr \\ fizfilo@gmail.com
}

\begin{abstract}
ÖSSZEFOGLALÁS
Milyen következményeket hordoznak a matematika nemteljességi tételei a fizika várva várt végső elméletére nézve? Ha a végső elméletre mint a fizika által elénk tárt természetet leíró modellre tekintünk, a tételeknek nincs következményük. Más a helyzet, ha a mindenség elméletét mint világmagyarázó metafizikai elvet képzeljük el, ekkor a nemteljességi tételek valós problémát szülnek. A tanulmány részletesen megvizsgálja mindkét esetet, és röviden ismerteti Gödel első és második tételét. Végül rávilágít, hogy egyetlen tisztán fizikai elmélet sem lehet konzisztens világmagyarázó elv, mert ebben az esetben önmagát is magyarázná.
\end{abstract}

\section{ABSTRACT}

What kind of inferences are carried by the incompleteness theorems of mathematics connected to the long awaited final theorem of physics. Analyzing the final theorem as a description of nature presented by physics, the thesis hasn't got an issue. Moreover, if we imagine the theory of everything as a theory explaining the world, then the incompleteness theorems bring up real problems. The essay analyses the two cases in detail and reviews briefly Gödel's first and second theories. Finally it argues, that no purely physical theory can be a consistent world explaining theory as in this case it would explain itself.

Kulcsszavak: Gödel nemteljességi tételei, mindenség elmélete, matematika filozófiája, metafizika, Jáki Szaniszló, Stephen Hawking

Keywords: Gödel's incompleteness theorems, theory of everything, philosophy of mathematics, metaphysics, Stanly L. Jáki, Stephen Hawking

„Néhány ember nagyon csalódott lesz, hogy nincs olyan végső elmélet, amely véges számú alapelvként fogalmazható meg. Régebben én is ezek táborába tartoztam, de megváltoztattam a véleményemet. Most örülök, hogy a kutatás soha nem ér véget, és a felfedezések minidig új kihívásokat teremtenek. Gödel tétele bizonyította, hogy a matematikusok munkája soha nem ér véget. Azt hiszem, az »M« elmélet ugyanezt fogja hozni a fizikusok számára."

Stephen Hawking (2018) 
A címben feltett kérdés megválaszolásához elöször Kurt Gödel híres nemteljességi tételeit kell megismernünk. A tételeket sokan különböző formában fogalmazták meg, és nem egyszer oly területeken használják, amelyek egyáltalán nem tartoznak hatóköreik alá. A magam részéről az I. tételt Barkley Rosser megfogalmazásában (Torkel, 2014) igyekszem bemutatni, mert talán ez a matematikai leírás világít rá a legjobban a tétel érvényességi körére: Bármely konzisztens formális rendszerben, amely magában foglalja az aritmetika egy részét, létezik olyan állitás, amely nem bizonyitható és nem is cáfolható a rendszer keretein belül.

Gödel II. tétele a konzisztencia kérdésére vonatkozik: Bármely formális rendszer, amely magában foglalja az aritmetika egy részét, konzisztenciája nem bizonyitható és nem cáfolható a rendszer keretein belül.

Fontos megjegyeznem, hogy Gödel tételei csak a matematikai rendszerek egy részében érvényesek, nem alkalmazhatóak a számokat vagy a formális nyelvezetet nélkülöző euklideszi geometriában, humán és társadalomtudományokban vagy bármely hasonló rendszerben. Jogos a kérdés: érvényesek-e a fizika törvényeire is? Ma még nem rendelkezünk egységes fizikai elmélettel, amelyekböl legalább elviekben levezethető lenne a természet valamennyi jelensége. Az úgynevezett nagy egyesített elmélet, amelyet Stephen Hawking nagy sikerủ tudománynépszerüsítő munkája nyomán a mindenség elméleteként ismerünk, pontosan ezt a célt tüzi maga elé. Az elmélet hosszú évtizedek óta várat magára. A fizikusok körében mégis él a hit, hogy létezik ilyen elmélet, és nem járunk messze a felállításától. Érvényes lehet-e Gödel tétele egy ilyen elméletre, és ha igen, milyen következményeket vonz maga után?

\section{FIZIKAI ELMÉLETEK ÉS GÖDEL TÉTELEI}

Először nézzük meg, hogy a fizika várva várt egyesített elmélete kielégíti-e a fenti feltételeket! Először a konzisztencia kérdését kell megvizsgálnunk. Nem kell sokat érvelnünk a fizika konzisztenciája mellett, vagy legalábbis az egyesített elmélet konzisztens voltát illetően. Nyilvánvalóan következetes, nélkülözi az ellentmondásokat, és a logika elemi szabályai szerint müködik. A második nemteljességi tétel nem azt zárja ki, hogy egy elmélet konzisztens lehet, csupán azt, hogy a rendszer keretei között mindez nem bizonyítható, mindennek a részletes vizsgálatára később még visszatérünk. A formális rendszer kérdésének vizsgálata sem jelent komoly problémát, hiszen e folyóirat olvasói jól tudják, hogy a fizika tudománya formális jelek segítségével írja fel a különböző fizikai mennyiségeket, és ezek között logikai kapcsolatokat keres. Látszólag az aritmetikát is könnyedén magunk mögött tudhatnánk, mondván, a fizika számokkal operál. A helyzet mégsem ilyen egyszerủ. A fizikai elméletek valóban tartalmazzák a számokat? Jól emlékszem, egyetemista koromban az egyik elméleti fizika zárthelyire nem 
vittem magammal számológépet. Először nagyon megrémültem, de mihelyt átgondoltam a helyzetet, egyáltalán nem féltem. Hamar rádöbbentem, hogy a feladatokhoz nem kapunk számokat, csak a fizikai jelek segítségével „,számolunk”, végig paraméteresen. A nosztalgikus visszaemlékezés jól rávilágít arra, hogy a fizikai elméletek nem feltétlenül tartalmazzák a számokat (Székely, 2013). Természetesen badarság lenne azt állítani, hogy a fizika nem operál számokkal, ezeket azonban nem a saját elméletéből vezeti le, hanem a matematikától kölcsönzi. A fizikai elméletek és a tapasztalat között a számok teremtik meg a kapcsolatot. Felírhatom a fizika talán legegyszerübb összefüggését, $v=s / t$, ez önmagában nem tartalmaz számokat, de számok nélkül használhatatlan, hiszen az összefüggés számok segítségével reprezentálja a fizikai valóságot. Fizikai elméleteink nem nélkülözhetik a matematika aritmetikai részét. A kérdés pusztán az, milyen következményeket hordoz magában egy olyan matematika használata, amely gödeli értelemben nem teljes? Mielőtt megválaszolnánk a kérdést, tisztáznunk kell, hogy pontosan mit értünk a fizika ,nagy” egyesített elmélete alatt.

\section{NAGY EGYESÍTÉS VAGY A MINDENSÉG ELMÉLETE}

A fizika „végső” elmélete kapcsán két megközelítéssel is találkozhatunk. Az első szerint egy olyan elmélet, amely a fizika ma ismert négy kölcsönhatását egyetlen rendszerben magyarázza, egyesíti a gravitáció és a kvantumfizika eddig ismert törvényeit. A húrelmélet vagy az „M”-elmélet területén dolgozó fizikusok pontosan ezt a célt tüzték maguk elé. A másik megközelítés az elöbbiből indul ki. Ha egyszer megtaláljuk az egyesített elméletet, amely ellentmondásmentesen írja le az összes kölcsönhatást, akkor az egész fizikai világot képesek leszünk ezen elmélet segítségével tárgyalni. Nem lesz szükség másra, csak ezen elméletre, és ebbool, ha kacifántos módon is, de levezethető minden jelenség, amellyel találkozhatunk. Az előbbi tudományos elméletként nem kíván mást, pusztán a négy kölcsönhatást egyetlen közös elméletben tárgyalni, míg az utóbbi egy tudományos elméletből kiinduló metafizikai elv, egyetlen fizikai elmélettel kívánja megválaszolni a világ eredetének minden rejtélyét. A követhetőség kedvéért az előbbit nevezzük egyesített elméletnek, míg utóbbit a mindenség elméletének.

\section{EGYESÍTETT ELMÉLET ÉS GÖDEL TÉTELE}

Az egyesített elmélet felállításához nyilvánvalóan szükségünk van valamiféle matematikára, amelyre Gödel nemteljességi tételei is érvényesek. A fizikai elméletnek mindezzel nem sok gondja van. Gödel tétele nem azt állítja, hogy a matematika kijelentései végső soron bizonyíthatatlanok lennének, vagy azt, hogy 
bizonyos tételek a matematikában nem bizonyíthatóak, mindössze annyit állít, hogy a fenti kritériumoknak megfelelő rendszerekben mindig lesznek bizonyíthatatlan állítások. Egy kibővített rendszerben, új axiómák felvételével, az adott állítás igazolható lehet. A kibővített rendszerben újabb bizonyíthatatlan állítások jelennek meg, de a korábbi kérdéses tételt egy új rendszerben igazolhatjuk. Ha sikerül egy olyan matematikai rendszert alkotni - Gödel I. tétele alapján erre minden esélyünk megvan -, amelyben a fizika számára fontos állítások egytöl-egyig igazolhatók, akkor az egyesített elméletet kivonhatjuk Gödel I. tételének érvényességi köre alól. A matematikusoknak egyáltalán nem nehéz megalkotni egy olyan matematikát, amelyben a fizika számára szükséges matematikai állítások egytől egyig igazolhatóak, maradnak ugyan bizonyíthatatlan tételek, de ezekre a fizika egyesített elméletének nincs szüksége. Gödel II. tétele rémisztőbbnek tűnik, hiszen azt állítja, hogy egy aritmetikát tartalmazó matematikai rendszer nem tudja bizonyítani saját konzisztenciáját. A félreértések elkerülése végett fontos leszögezni, hogy e tétel nem azt jelenti, hogy egy rendszer nem konzisztens, hanem azt, hogy konzisztenciája nem bizonyítható a rendszer keretei között. Ha a matematika nem vezet ellentmondásra a fizikai világ leírása során, reprezentálja az elméleti és a kísérleti tapasztalatokat, akkor fizikai szempontból mindenképpen konzisztensnek tekinthető. Ha az egyesített elmélet célként csak annyit tủz ki, hogy egyesítse a ma ismert négy fizikai kölcsönhatást, és nem szeretne mindent, például a matematikát is megmagyarázni, akkor Gödel tételeinek hatókörén kívül helyezkedik el.

\section{A MINDENSÉG ELMÉLETE ÉS GÖDEL TÉTELEI}

Gödel tételét először és talán legmarkánsabban Jáki Szaniszló (2004a) alkalmazta a fizika végső elméletével szemben. Nem vitatja a fizikai elméletek értelmességét, sőt elismeri, hogy elviekben semmi nem zárja ki annak a lehetőségét, hogy a fizikusok egyszer megalkothassák a mikrovilág és a gravitáció egyesített elméletét. Jáki az elmélet végső és konzisztens volta ellen tiltakozik. „Rátalálhatnak egy elméletre, amelyik abban a pillanatban formulái segítségével magyarázatot ad minden ismert fizikai jelenségre. De Gödel tétele értelmében egy ilyen elmélet nem tartható olyasminek, ami szükségképpen igaz." (Jáki, 2004b)

Az előző bekezdések alapján a mindenség elméletét kiegészíthetjük egy kritériumrendszerrel, amely megadja, hogy a matematika mely részei relevánsak a fizikában, ezzel a bizonyíthatatlan gödeli állításokat elszigetelhetjük. A Templeton-díjas Jáki által felvetett probléma ennek ellenére megmarad. Ha a mindenség elmélete mindenre választ kíván adni, akkor a matematika azon részét is tartalmazza, amelyben a gödeli állítások megfogalmazódnak, vagyis lesznek bizonyíthatatlan állítások. Másfelől a kritériumrendszer felállítása a rendszer 
esetlegességét vonja maga után, hiszen mi garantálja, hogy a kritériumrendszer mindig minden jelenségre érvényes?

Talán meglepö, de nagyon hasonló eredményre jutott Stephen Hawking. A nyolcvanas években megjelentetett $A z$ idö rövid története címü könyvében (magyar nyelven Hawking, 2010) fogalmazza meg a mindenség elméletének filozófiai programját, amelyben a fizika végső elméletét világmagyarázó elvvé formálja, olyan rendszerré, amelyben az univerzum titkainak megértéséhez nincs szükség Istenre. Nézeteit későbbi ismeretterjesztő munkáiban is hangoztatta. A várva várt mindenség elméletének elmaradása, a gravitáció és a kvantumfizika összeegyeztetéséből adódó egyre súlyosabb problémák és nem utolsósorban Gödel tételei arra indították Hawkingot, hogy korábbi nézeteit módosítva a fizika elméleteit ne tekintse teljesnek és konzisztensnek: „Ha léteznek matematikai állítások, amelyek nem bizonyíthatóak, akkor vannak fizikai problémák, amelyek nem jelezhetőek elöre.” (Hawking, 2018)

Hawking talán éppen Jáki Szaniszló munkássága nyomán ${ }^{1}$ terjesztette ki a fizikára Gödel nemteljességi tételét. Az előadást tovább olvasva felfigyelhetünk egy újabb gondolatra, mely szigorúan véve nem tartozik Gödel tételének hatálya alá, valójában a mindenség elmélete és a matematika kapcsolatát érinti. A fizika végső elmélete leírja a csillagok képződését, a bolygók kialakulását, a bolygók felszínén megjelenő anyagokat és a belölük létrejövő életet, végül az embert, nem utolsósorban az emberi elmét is, amelyben megjelenik a mindenség elmélete. Ha komolyan vesszük, hogy a mindenség elmélete nemcsak a négy fizikai kölcsönhatást, hanem az univerzum valamennyi megfigyelhető jelenségét leírja, beleértve a fizikusok elméjét is, akkor nem kerülhetjük el, hogy az elmélet ne önmagát magyarázza: „Mi azonban nem vagyunk angyalok, akik az univerzumra külső szemlélőként tekintenénk. A modelljeinkkel együtt az univerzum részei vagyunk. A fizikai elméletek önreferensek, úgy, mint a gödeli mondatok. Emiatt számítanunk kell arra, hogy inkonzisztensek vagy nem teljesek." (Hawking, 2018)

Hawking iménti gondolatával elhagyja a szigorú értelemben vett gödeli nemteljességet, de analóg formában rávilágít arra, hogy a mindenség elmélete nem lehet végső és konzisztens, mindent magyarázó elv.

\section{ÖSSZEGZÉS}

Gödel tételei mindaddig nem okoznak semmiféle problémát a fizika bármely elméletének, legyen az az egyesített elmélet, a newtoni mechanika vagy egy ma még ismeretlen fizika, ameddig a fizika megmarad fizikának, és nem kíván világmagyarázó elvvé válni. Egy jól körülhatárolt elmélet, amely nem lép túl saját

\footnotetext{
${ }^{1}$ Hawking és Jáki levelezésben álltak egymással.
} 
keretein, védett a nemteljesség problémájától. A mindenség magragadását célzó végső elméletnek, amely nemcsak fizika, hanem metafizika kíván lenni, szembe kell néznie a Gödel tételei szülte kihívásokkal és talán még ezeknél is súlyosabb problémákkal. A jól ismert közmondást idézve: Suszter maradjon a kaptafánál!, azaz a fizikus ne kívánjon mindenre válaszolni, mert akkor beleütközik a saját tudománya szabta keretekbe.

Végül le kell szögeznünk, hogy Gödel tételei nem a tudomány igazságait kérdöjelezik meg, csak rávilágítanak azok határaira. Nem utolsósorban a gödeli mondatok optimizmussal kell hogy eltöltsenek minden fiatal kutatót. A fizikában mindig lesznek megválaszolatlan kérdések, amelyekre egy új, kibővített fizikában válaszokat lelhetünk. A fiatal generációk munkája soha nem ér véget.

\section{IRODALOM}

Hawking, S. (2010): Az idő rövid története. (ford. Molnár István, Egri Győző) Budapest: Akkord Kiadó

Hawking, S. (2018): Gödel and the End of the Universe. http://www.hawking.org.uk/godel-andthe-end-of-physics.html

Jáki Sz. (2004a): A fizika látóhatárán. Budapest: Kairosz Kiadó

Jáki Sz. (2004b): Megkésett ébredés: Gödel a fizikában. Fizikai Szemle, 10, 338-343.

Székely L. (2013): A fizikai megismerés határairól és határtalanságáról. Pannonhalmi Szemle, XXI/4, 26-27.

Torkel, F. (2014): Gödel nemteljességi tételei. (ford. Csaba Ferenc) Budapest: Typotex Kiadó 